interests of all those responsible for the increasingly high quality achieved in these productions. In Communication 64 (Pp. 56. London: The British Association of Industrial Editors, Ltd., 1964. 5s.), a review prepared by the British Association of Industrial Editors, there occurs this statement which clearly epitomizes the aims of this Association: "Communication can be the O.K. formula word, the fashionable word of industry, the vague, facile excuse word, the all-things-to-all-pseuds word. Properly considered it can be the key to understanding between individuals, groups and nations - the supreme aim of civilized society. Over a decade ago the President of the American Management Association said: 'The number one management problem to-day is communication'. The problem remains. This survey takes a realistic look at an ingredient vital to industrial and social progress". Among the articles in the present publication are "The Future of Mass Communications", by I. Colquhoun; "Men, Management and Morale in Efficient Business", wherein industrial relations and the importance of the systematic approach are reviewed by J. Garnett; "Walls between People", the eccentricities and idiosyncrasies which provide obstacles to communication, by G. C. B. Andrew; "The Meaning of B.A.I.E.", the growth of the Association from enthusiastic amateurs to professional status, detailed by G. Phillips; "British Editor: Industrial Species", a description of the presentday role of the industrial editor in Great Britain, by R. C. E. Dancer; "The Communicators"-being interviews with five leaders of industry on the role of communications; "Case Studies", some examples of success and failure in house journals analysed by E. H. Dodimead. This publication sets a standard not only in subject-matter and illustration, but also in style and presentation of the message it seeks to convey; if industrial editors responsible for house magazines, either established or at present only at planning stage, can emulate it, they will not go far wrong.

\section{Needs of the Scientific Writer}

IN a paper read at a Library Circle meeting of the Royal Institution in March 1964, and now published in the Proceedings of the Institution (No. 182, 40; 1964), Mr. J. G. Crowther describes with insight the dependence of the scientific writer on library facilities and the characteristics of the facilities such writers need. His warning that more technical efficiency is insufficient is timely, but Mr. Crowther could well have mentioned also the need for an easy and rapid moans of verifying references and quotations. Mr. Crowther refers appreciatively to the establishmont of the National Lending Library for Science and Technology. His talk deserves attention from the Committee on Libraries of the University Grants Committee, as well as elsewhere, for it points to some gaps in the national library system which call for imaginative attention. The scientific writer has an important part to play in spreading a general understanding of science and technology and in raising productivity, and he cannot do so with full efficiency unless these library needs are met.

\section{New Zealand Forestry}

THE annual report of the Director-General of Forests, New Zealand, for the year ended March 31, 1964, makes very interesting reading ( $\mathrm{Pp} .59$. Wellington: Government Printer, 1964. 2s. 6d.). New Zealand's forest economy is largely dependent on her exotic coniferous forests, and now they have three times the output of the indigenous forests. More than this, the annual exports of forest products have risen in the past ten years from less than $£ 1$ million to nearly $£ 11$ million. This prosperity is to a great extent associated with the rapid rise of the pulp and paper industry, for more than three-quarters of the 1963 exports was due to newsprint and pulp. Indeed, it is significant that these two items accounted for nearly half New Zealand's exports to Australia, and forest products now rank high in a country which is traditionally associated with agricultural produce only. There is plenty of land available for acquisition by the Forest Service, especially land that is marginal for agriculture. But some unsuitable land is being offered because would-be sellers too often look on forestry as a form of land use to take over where agriculture has failed. With the availability of land as it is, there is every likelihood that there will be an increased rate of planting by both State and companies, although private planting may have to be given incentives because during the past 30 years it has lost some of its public appeal as a commercial investment. The New Zealand Forest Service provides a vigilant timber inspection. Packing-cases are regarded as one of the most dangerous means of entry of forest insects into the country. There is the not unusual animal-control controversy, but the Forest Service insists that its policy is to enforce proper control and not to exterminate. Over-population of noxious wild animals on catchment areas can sometimes be associated with flooding. Forestry in New Zealand continues to prosper in a very convincing manner.

\section{Bibliography on British Soils}

INFORMATION on soils is presented in such a large number of scientific journals and memoirs that it is often difficult for anyone not actually engaged in soil science investigations to decide where to look for appropriate reliable data. It was with this in view that $A n$ Annotated Bibliography of Memoirs and Papers on the Soils of the British Isles, by B. T. Bunting, was published in time for the twentieth International Geographical Congress (London) and the eighth International Congress of Soil Science (Bucharest) (Part 1: The Classification, Morphology, Distribution and Reclamation of British Soils. Pp. iv + 100. London: Geomorphological Abstracts, Department of Geography, London School of Economics, 1964. 10s.). In the main, it includes papers dating from 1920 . Authors and titles are given with occasional crossreferences and, in many cases, an abstract is added. Part 1 of the Bibliography deals with classification, morphology, distribution and reclamation, and consists of two parts: the first is of 11 sections on systematic and general papers, the second is on regional and local papers for 16 regions. There is an author index. A second volume (Part 2) is planned to deal with the internal properties and external relationships of British soils.

\section{Odour in Theory and Practice}

INCREASING specialization brings with it the advantage that every available scientific and technical approach can be brought to bear on a single problem. Odour is a case in point. Its practical importance is so great in so many ways that it is scarcely surprising to find numerous laboratories devoted solely or mainly to the investigation of various aspects of the chemistry, physiology, psychology, measurement, analysis, correlation, control and production of odours and fragrances. These topics are described in the report of a conference entitled Recent Advances in Odor : Theory, Measurement, and Control (Annals of the New York Academy of Sciences. Vol. 116, Article 2. By Richard L. Kuehner and 60 other authors. Pp. 357-746. New York: New York Academy of Sciences, 1964). What emerges from this comprehensive account is the complexity of the subject and the realization that perception of odour, particularly by a trained perfumer, often still exceeds the sensitivity of vapour phase chromatography. To someone who is not a specialist in the field of odour research, its ramifications come as a surprise. To begin with, atmospheric pollution, especially by particular industries, is a source of odour which was tolerated by local residents in the past but is now no longer acceptable. Odour control in the crowded urban environment, both outdoors and indoors, assumes equal importance with reduction of noise. Body odour and deodorants are a fertile field of research. The importance of odour or fragrance in market- 